\title{
KÖZLEMÉNYEK
}

\section{BEZERÉD-TELEKI-DÛLŐ II. EGY KÉSŐ NEOLITIKUS KÖRÁROK A KR. E. 5. ÉVEZREDBŐL}

\author{
P. BARna Judit-Tokai Zita Mária-EKe István-PÁsZtor Emília-T. Biró Katalin- \\ MESTERHÁZy GÁBOR-PETHE MiHÁLY*
}

\begin{abstract}
Bezeréd-Teleki-dülő II. lelőhelyen terepbejárás és geofizikai felmérés eredményeként a késő neolitikus lengyeli kultúra körárka vált ismertté. A feltünöen szimmetrikus alaprajzú, kettős körárok mindkét árkán 8-8 bejárat figyelhetö meg, melyek némelyike előtt félkörives toldalékok jelentkeztek. A belső árok mindkét oldalán paliszádárkok mutatkoztak. A kapuk tájolása megfelel a dunántúli lengyeli körárkokra jellemzö mintázatnak. A körárok belsejében kirajzolódó épületek, a körárok körüli lengyeli kultúrás lelőhelyek, továbbá a körárok időrendi viszonya egyelöre nem tisztázott.

Kulcsszavak: késő neolitikum, lengyeli kultúra, körárok, geofizikai felmérés, archeoasztronómia

As a result of a field walk and a geophysical survey, a circular enclosure (rondel) of the Late Neolithic Lengyel culture was discovered at a site at Bezeréd-Teleki-dülö II. Eight gates can be seen on both ditches of the markedly symmetrical double circular enclosure; in front of some of them, semi-circular affixes could be seen. Ditches of palisades were visible on both sides of the inner ditch. The alignment of the gates matches the pattern typical for the alignment of the circular enclosures in Western Hungary. The chronological relationship among the buildings outlined inside the circular enclosure, the Lengyel culture sites around the circular enclosure and the circular enclosure itself is not yet clarified.
\end{abstract}

Keywords: Late Neolithic, Lengyel culture, circular enclosure, geophysical measurement, archaeoastronomy

Az alábbi munka célja a Zala megyei BezerédTeleki-dúlő II. lelőhelyen 2014-ben felfedezett késő neolitikus körárok előzetes ismertetése (1. kép 7). A lelőhely vizsgálata része a Balatoni Múzeum vezetésével 2011-ben alakult interdiszciplináris kutatócsoport munkájának, mely célul túzte ki Zala megye őskori földmúveinek - köz- tük a neolitikus körárkoknak - a felkutatását és a lehetőségekhez mért minél szélesebb körú megismerését. Szándékunk a földmúveknek mint mesterséges tájformáló jelenségeknek a természeti környezetükben való vizsgálata, valamint az őskori településhálózatban betöltött szerepük tanulmányozása. A természeti környezet szerves

A kézirat beérkezett: 2018. április 4 .

* P. Barna Judit: Balatoni Múzeum, 8360 Keszthely, Múzeum u. 2; e-mail: judit.pbarna@balatonimuzeum.hu. Tokai Zita Mária: Budavári Ingatlanfejlesztő és Üzemeltető Nonprofit Kft., 1113 Budapest, Daróczi út. 3; e-mail: tokaizita@gmail.com. Eke István: Göcseji Múzeum, 8900 Zalaegerszeg, Batthyány u. 2; e-mail: eke.istvan@zmmi.hu. Pásztor Emília: Türr István Múzeum, 6500 Baja, Deák Ferenc u. 1; e-mail: pasztoremilia@tolna.net; T. Biró Katalin: Magyar Nemzeti Múzeum, 1088 Budapest, Múzeum krt. 14- 16; e-mail: tbk@hnm.hu. Mesterházy Gábor: Budavári Ingatlanfejlesztő és Üzemeltetó Nonprofit Kft., 1113 Budapest, Daróczi út. 3; e-mail: gabor.mesterhazy@gmail.com. Pethe Mihály: Budavári Ingatlanfejlesztő és Üzemeltető Nonprofit Kft., 1113 Budapest, Daróczi út. 3; e-mail: mihaly.pethe@forsterkozpont.hu 


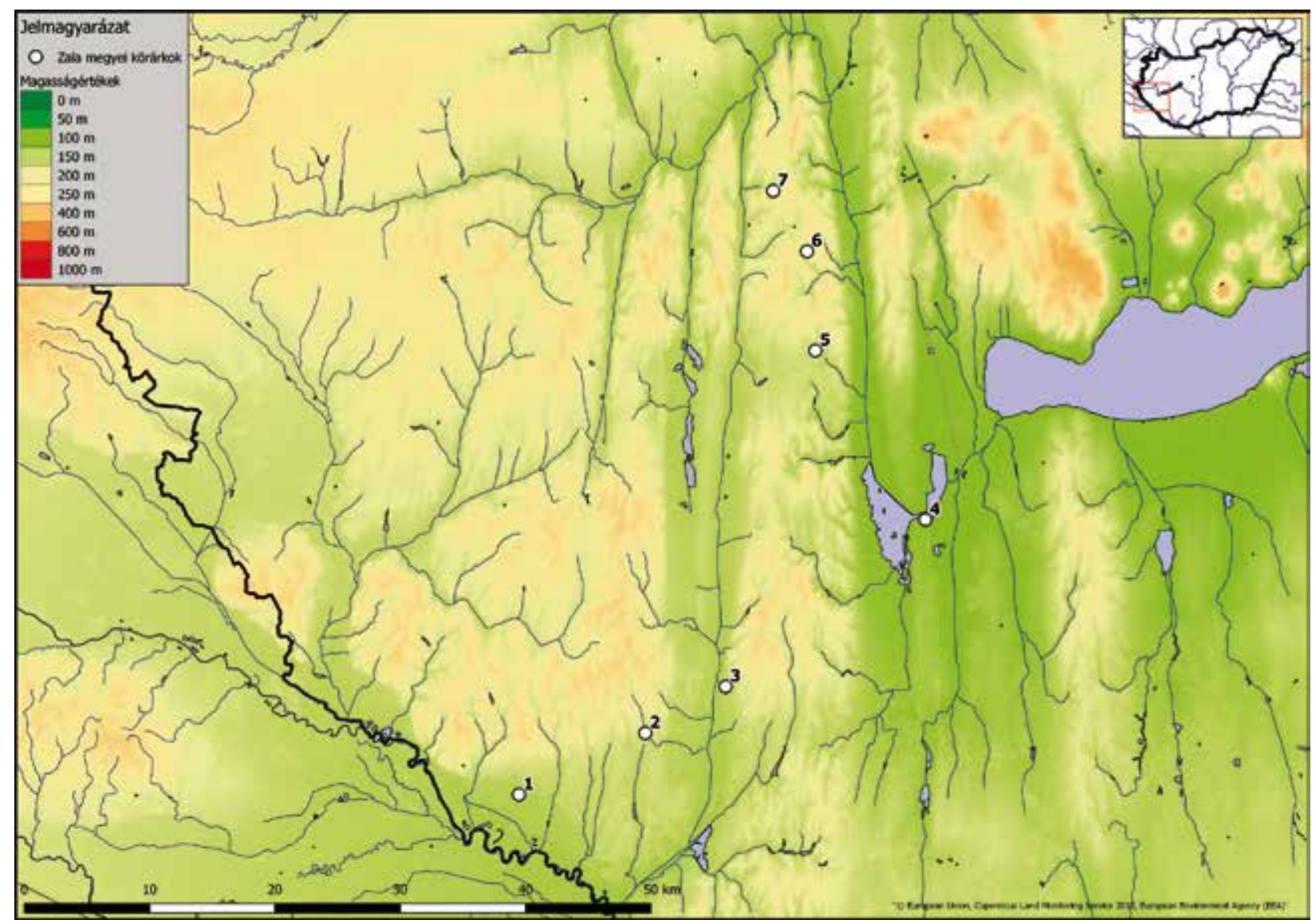

1. kép. 1.1-7 A Zala megyei körárkok elterjedése. 1 Becsehely-Gesztenyés; 2 Sormás-Török-földek I; 3 Nagykanizsa-Palin, Anyagnyerőhely; 4 Balatonmagyaród-Hídvégpuszta; 5 Gétye-Gyomgyáló-lejtős; 6 Ligetfalva-Gesztenyési-dúlö; 7 BezerédTeleki-dúlő II

Fig. 1. Distribution of circular enclosures in Zala County: 1 Becsehely-Gesztenyés; 2 Sormás-Török-földek I; 3 NagykanizsaPalin, Anyagnyerőhely; 4 Balatonmagyaród-Hídvégpuszta; 5 Gétye-Gyomgyáló-lejtős; 6 Ligetfalva-Gesztenyési-dúlő; 7 Bezeréd-Teleki-dúlő II

részének tekintjük az égboltot is, ezért szintén vizsgáljuk az égi jelenségekkel való összefüggéseket, elsősorban a körárkok tájolásával kapcsolatban. Jelenleg hét késó neolitikus körárok ismert a megyében, melyekből három felfedezése már kutatócsoportunkhoz köthetó (1. kép 5-7). Ez a hét körárok meglehetősen változatos képet mutat mind alaprajzuk - pl. az árkok száma, a kapuk kialakítása -, mind pedig a lengyeli kultúrán belüli relatív kronológiai helyzetük tekintetében. ${ }^{1}$ Az elterjedési térkép inkább tükrözi a Zala megyei körárkok kutatottságának jelenlegi állapotát, mintsem valós elterjedését. Az azonban jól látszik, hogy még számos hasonló domborzati viszonyokkal rendelkező terület vár kutatásra a megyében, így a jövőben várható a körárkos lelőhelyek számának emelkedése.

A bezerédi körárkot 2014 tavaszán múholdfelvételen fedeztük fel. ${ }^{2} \mathrm{Az}$ észlelt jelenség elszínező-

1 P. BARNA et al. 2015; P. BARNA et al. 2016.

2 Google Earth 2014.04.13. dése élesen rajzolódik ki olyannyira, hogy - mint utóbb, a geofizikai felmérés birtokában felismertük - még kisebb szerkezeti elemek is beazonosíthatók a felvételen. ${ }^{3}$ A lelőhely már korábbról is ismert volt, s mivel az 1996-1997-ben végzett terepbejárás során a lengyeli kultúra leletei is elókerültek innen, ${ }^{4}$ még inkább valószínúsíthető volt, hogy a megfigyelt elszíneződés egy neolitikus körárok. Ennek igazolására újabb kisebb terepbejárást és geofizikai felmérést végeztünk.

\section{A lelőhely}

Bezeréd település Zala megyében, a Zalaapátihát kistáj északi részén található. A Zalaapáti-hát egy hosszan elnyúló, észak-déli irányú dombvonulat, ami a Zala folyó és a Principális-völgy között terül el.

3 P. BARNA et al. 2016, Fig. 14.

4 Göcseji Múzeum Adattár ADF 2308-2001. 
Bezeréd határában több, a lengyeli kultúra korszakába sorolható régészeti lelóhely fekszik (2. kép). A falutól északra található a „BezerédKastély-hely" lelóhely (azonosító: 20310), ahol Horváth Jolán 1967-ben, majd H. Simon Katalin és Horváth László András végeztek régészeti terepbejárást, és találták meg a lengyeli kultúra leleteit. ${ }^{5}$

A településtől délre, a Teleki-dúlő területén öt régészeti lelőhely ismert (Bezeréd-Teleki-dúlő I-V.). ${ }^{6}$ Mind az öt lelőhely területén szép számmal találhatók a lengyeli kultúrához köthetó leletek, ${ }^{7}$ továbbá az 1996-1997-ben végzett terepbejárás során őskori leletanyag mellett középkori és török kori leletek is előkerültek. Bezeréd közelében kell keresnünk a középkori Telek nevú falut, melynek okleveles említése 1412-ből származik. ${ }^{8}$ A település valószínúleg a Teleki-dúlő területén feküdt.

A legnagyobb kiterjedésú lelőhely BezerédTeleki-dúló II. (lelőhely-azonosító: 20307) egy a környezetéből jelentősen, több mint 35 méterrel kiemelkedő domb felső részén található. A domb teteje lapos, nagy kiterjedésú plató. A lelőhelyről készült légi fotókon, ${ }^{9}$ illetve múholdképeken egy megközelítőleg kör alakú, nagyméretú anomália látható. A terület kisebb részének bejárására, illetve a lelőhely középső részének geofizikai felmérésére 2014 őszén került sor.

\section{A leletanyag, a lelóhely kora}

A lelóhelyen két alkalommal kevés, ${ }^{10}$ de jellegzetes felszíni leletet, kerámiatöredékeket és kóeszközöket gyújtöttünk, noha szisztematikus terepbejárásra nem került sor. A mezőgazdasági múvelés alatt álló területet mindkét alkalommal növényzet fedte, így a megfigyelési lehetőségek erőteljesen korlátozottak voltak. A lengyeli kultúra kerámialeletei mellett főként kőeszközöket, továbbá kevés középkori kerámiatöredéket gyújtöttünk. A lelőhely korát meghatározó leleteket egy kb. 2-3 m széles, frissen szántott sávban gyújtöttük a dombtetón és a nyugati domboldalban. Mindezek tükrében a leletanyagról egyelőre nagyon kevés információval rendelkezünk, így csak egy vázlatos képet tudunk adni.

\footnotetext{
5 HorvÁth-H. SimON 2003, 54-55. A lelőhely Bezeréd-Temetőidúlő néven szerepel.

6 A lelőhelyek azonosítói (számozás szerinti sorrendben): 20306, 20307, 20308, 20309 és 20312.

7 Göcseji Múzeum Adattár 2075-97.

8 Holub 1933.

www.fentrol.hu $\left(1985,132 \_6938\right)$.

10 2014.10.03; 2014.11.05.
}

Kerámia. Többségük erősen kopott, soványításuk csillámos homokos és kerámiazúzalékos. A töredékek tálak, kis csuprok és csészék, csőtalpas edények, nagyobb fazekak darabjai. A peremek között elvékonyodó, megvastagodó és ujjbenyomással tagolt példányok is vannak (3. kép 1, 3-4, 13). Közülük a megvastagodó és ujjbenyomással tagolt példányok a klasszikus és a késői időszakban válnak gyakoribbá. A gyújtött aljtöredékek belseje vastagabb, egyenetlen eldolgozású (3. kép 16-17). Edények oldalát, vállát, hasát, élesebb törésvonalát díszítő és egyben funkcionális bütyköket változatos formában - kerek, gömbös, enyhén ovális, nyeles, ujjbenyomásos, átfúrt - és méretben - apró, meggyszem nagyságú és kicsit nagyobb - találtunk (3. kép 2, 5-12). Közülük az alig hangsúlyos bütyök a korai időszakban jellemző; a lapos tetejú bütykök a formatív fázisban még nincsenek, a korai klasszikus fázistól terjednek el; a felületből kiemelkedő gömbös bütykök zömében a klasszikus szakaszban jelennek meg. A bütykök két kivétellel mind edények felületéról letört darabok, így az edényen való helyzetük többnyire nem ítélhetô meg. Az egyik említett kivétel viszont valószínúleg csupor nyakhajlatában helyezkedik el, ami a fiatalabb lengyeli kultúra fazekasságára jellemző (3. kép 8). Egyúttal ez az egyetlen festett lelet, amelyen a bütykön lévő átfúrás tövében maradt meg egy apró felületen vörös festék.

A leletek között van egy simítótöredék is. Ezt egy törött edény füles darabjából másodlagosan alakították ki, amire a használattól lecsiszolódott széle utal (3. kép 15). Ezek a klasszikus és késő lengyeli időszakban jellemzőbbek.

Kőeszközök. A bezerédi lelőhely felszíni bejárása során összesen 49 darab kőeszköz került elő. Ebből a lelőhely egészére ugyanúgy nem tudunk végleges következtetéseket levonni, mint a felszínen gyújtött egyéb leletanyagból. A viszonylag nagyszámú kőeszköz mindenképpen a bejárásokat végzők éles szemét dicséri, különös tekintettel a begyújtött mikrolitokra: a gyújtött kőeszközök 57\%-a (28 db) nem éri el a $3 \mathrm{~cm}$ hosszméretet, és $1,5 \mathrm{~cm}$ alatti mikropengét, valamint $12 \mathrm{db}$ pattintékot is találtak. A gyújtött leletanyag feltétlenül alkalmas arra, hogy a nagyobb típuscsoportok és a lelőhelyen használt főbb kőeszköznyersanyagcsoportok megoszlását vizsgáljuk. ${ }^{11}$ A területi megoszlás, a rétegtani és kronológiai adatok remélhetően ezt a képet majd jelentősen kiegészítik és pontosítják.

A begyújtött kőanyag típus/nyersanyag mátrixát az 1. táblázat szemlélteti.

11 T. BIRÓ 1998. 


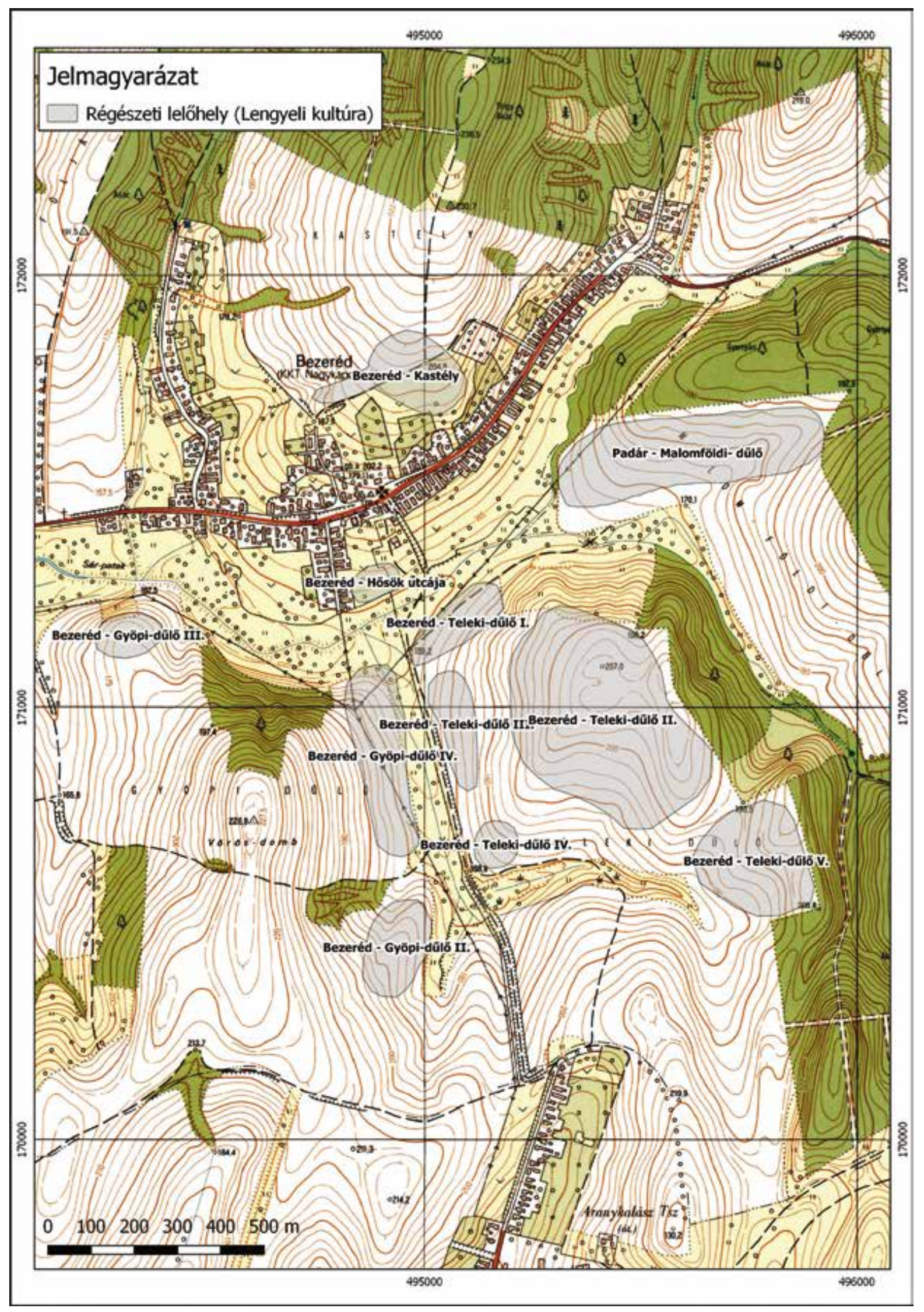

2. kép. Bezeréd-Teleki-dúlő II földrajzi környezete és ismert régészeti öröksége

Fig. 2. Geographical environment of the site Bezeréd-Teleki-dúlő II and its known archaeological heritage 


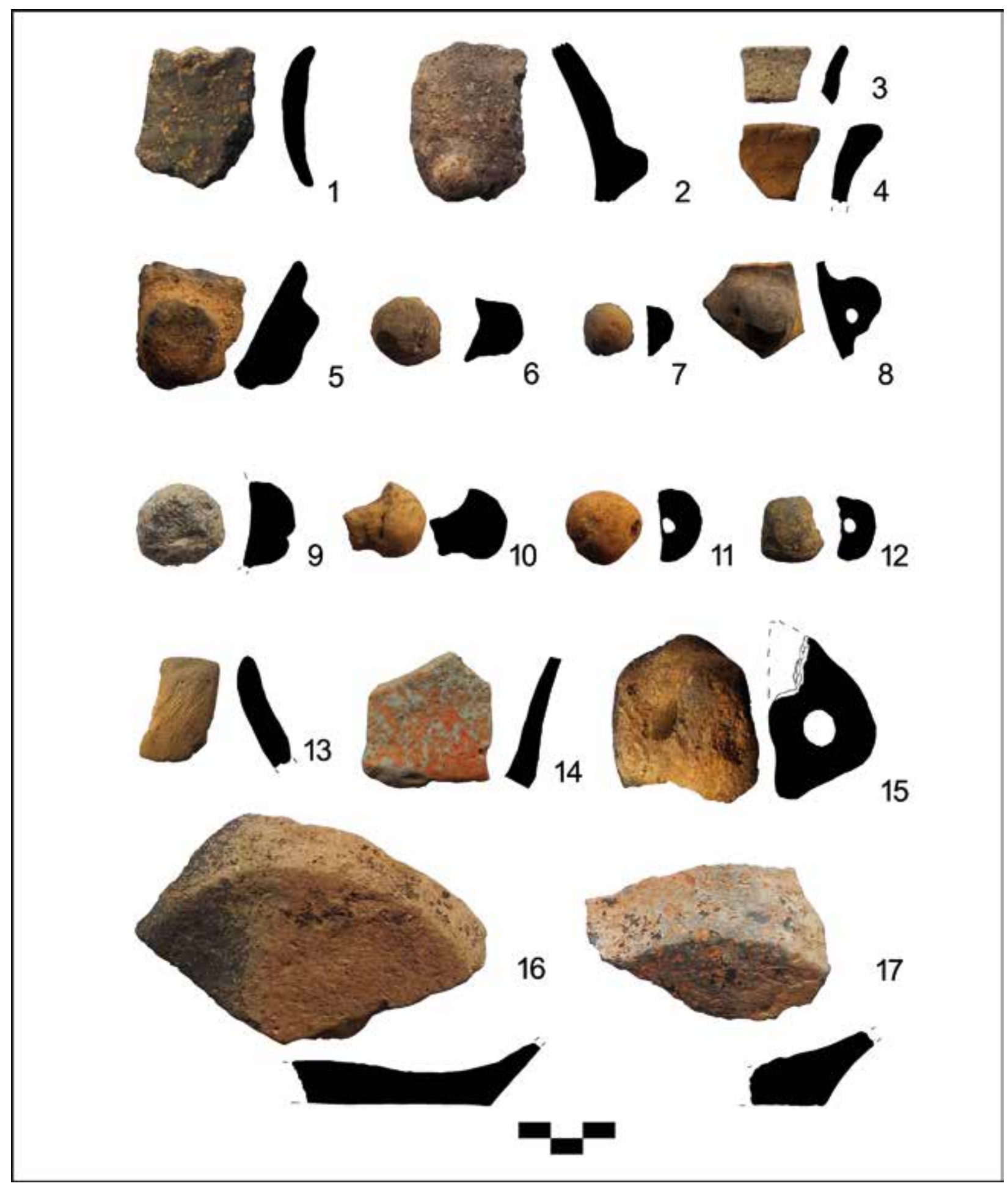

3. kép. Válogatás a felszíni gyújtés késő neolitikus kerámialeleteiből

Fig. 3. Selection of Late Neolithic pottery from surface collection 


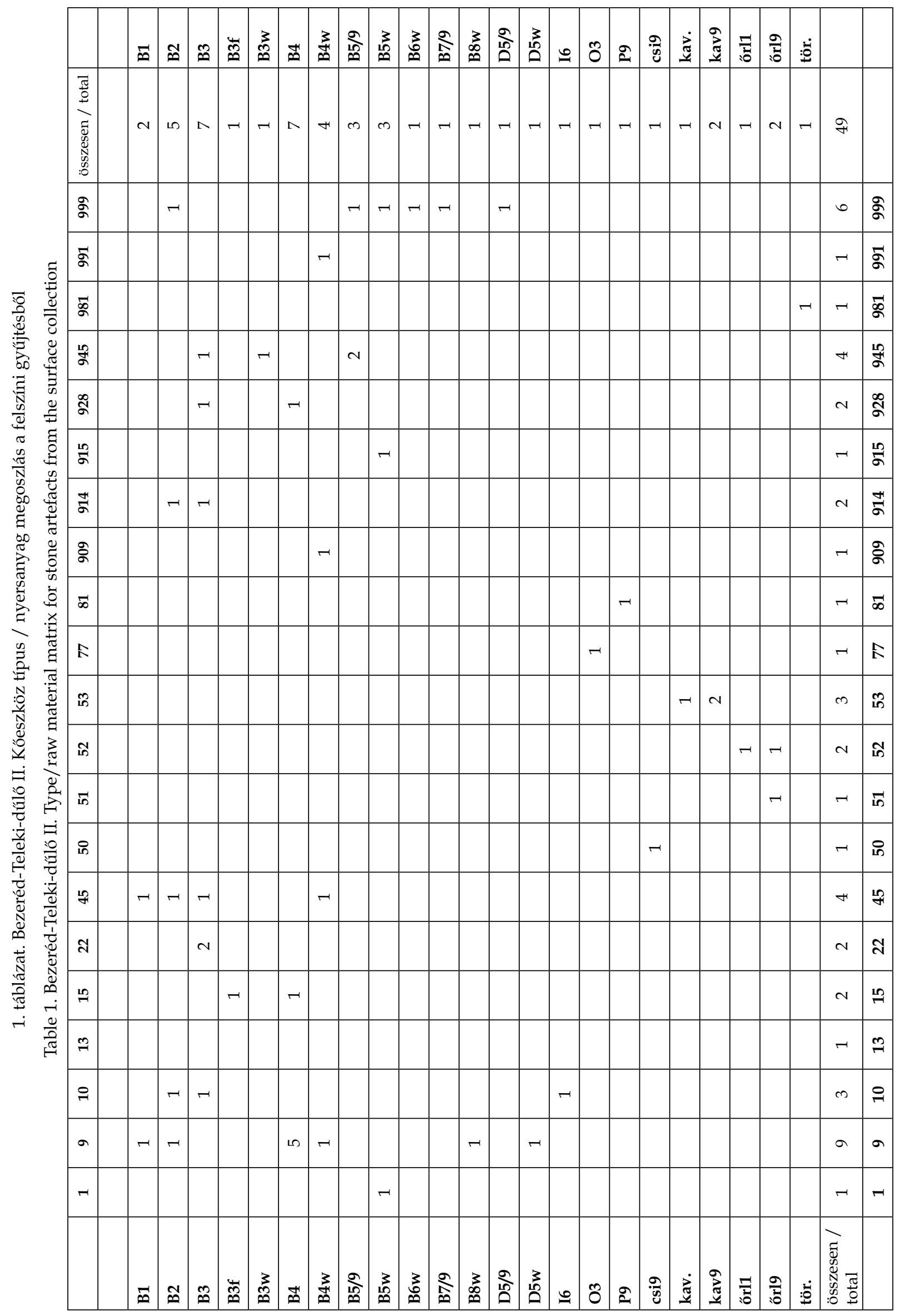


Jelkulcs:

Típuslista: B1: magkő; B2: magkőmaradék; B3: szilánk; B3f: szilánk, hegyes; B3w: mikroszilánk; B4: pattinték; B4w: apró pattinték; B5/9: pengetöredék; B5w: mikropenge; B6w: apró késpenge; B7/9: pengeszerú szilánktöredék; B8w: apró pengeszerú pattinték; D5/9: csonkított pengetöredék; D5w: csonkított mikropenge; I6: vakaró késpengén; O3: speciális eszköz szilánkon; P9: csiszolt kőeszköz töredéke; kav.: kavics; kav9: kavicstöredék; csi9: csiszolótöredék; őrl1: őrlőkónyersanyag; ôrl9: őrlőkőtöredék; tör.: töredék

Nyersanyaglista: 1: kárpáti 1. (szlovák) obszidián; 9: dunántúli radiolarit, szentgáli típus; 10: dunántúli radiolarit, úrkút-eplényi típus; 13: dunántúli radiolarit, vörösbarna; 15: dunántúli radiolarit, egyéb; 22: teveli túzkő; 45: felső triász szarukő, Balaton-felvidék; 50: finom szemú homokkő; 51: közepesen finom szemú homokkő; 52: durva homokkő; 53: kvarcit; 77: Becsehely-típusú szürke kova; 81: világos színú zöldpala (Felsőcsatár-típus); 909: dunántúli radiolarit, szentgáli típus?; 914: dunántúli radiolarit, sümegi típus?; 915: dunántúli radiolarit, egyéb?; 928: bakonyi liász túzkő?; 945: felső triász szarukő, Balaton-felvidék?; 981: világos színú zöldpala (Felsőcsatár-típus)?; 991: bosnyák vörös „radiolarit"?; 999: egyéb

Abbreviations in the Table:

Type list: B1: core; B2: core remnant; B3: flake; B3f: pointed flake; B3w: micro-flake; B4: chip; B4w: small chip; B5/9: blade fragment; B5w: micro-blade fragment; B6w: small knife-blade; B7/9: fragment of blade-like flake; B8w: small blade-like chip; D5/9: fragment of truncated blade; D5w: fragment of truncated micro-blade; I6: end-scraper on knife blade; O3: special tool on flake; P9: fragment of polished stone artefact; kav.: pebble; kav9: pebble fragment; csi9: polisher fragment; oorl1: raw material for grinding stone; őr19: grinding stone fragment; tör.: fragment

Raw material list: 1: C1 (Slovakian) obsidian; 9: Transdanubian radiolarite, Szentgál type; 10: Transdanubian radiolarite, ÚrkútEplény type; 13: Transdanubian radiolarite, reddish brown; 15: Transdanubian radiolarite, others; 22: Tevel flint; 45: Upper Triassic hornstone - Balaton-Highland; 50: fine grained sandstone; 51: medium fine grained sandstone; 52: coarse sandstone; 53: quartzite; 77: Becsehely type grey silex; 81: light coloured greenschist (Felsőcsatár type); 909: Transdanubian radiolarite Szentgál type?; 914: Transdanubian radiolarite, Sümegi-type?; 915: Transdanubian radiolarite, other?; 928: Liassic chert from Bakony Mts.?; 945: Upper Triassic hornstone - Balaton-Highland?; 981: light coloured greenschist (Felsőcsatár type)?; 991: Bosnian red "radiolarite"?; 999: others

A fó típuscsoportokat a 4. képen, a fő nyersanyagtípusokat az 5. képen láthatjuk.

A begyújtött kőeszközök között nincs nyersanyagdarab. Ez sokat nem árul el a lelóhelyről, mert a terepbejárás során nyilván a megmunkálás nyomait mutató darabokat keresték. Magkőből hét darab került elő (14\%), ami lakótelepen átlagos vagy annál kicsit magasabb érték. A szilánkok (és pattintékok) száma kiemelkedően magas, ami szintén jellemző a legtöbb településre $(21 \mathrm{db}$, $43 \%)$. A pengék darabszáma nyolc (16\%), ami a szilánkokhoz képest alárendelt mennyiség. Retusált eszköz összesen négy darab került elő, ami darabszám szerint és arányában is viszonylag kevés. Egy darab csiszolt kőeszköztöredéket gyújtöttek be, ami felsőcsatári zöldpalából készült. Ehhez képest jelentős a szerszámkövek száma (csiszolókő- és őrlőkőtöredékek). A retusált eszközök apró csonkított pengék és egy kisméretú vakaró, szintén pengén, amit egy nagyobb darab bifaciálisan retusált eszköz (félkész hegy?) egészít ki.

A legfontosabb nyersanyagtípusok a dunántúli radiolaritok különféle változatai (összesen 19 $\mathrm{db}$ ), elsősorban a szentgáli radiolarit (a radiolaritoknak több mint a fele). A jellegzetes dunántúli nyersanyagok közül jelen van a teveli túzkő $(2 \mathrm{db})$, a Balaton-felvidéki szarukő jelentős számban ( $8 \mathrm{db}$ ), a bakonyi liász túzkő és a dél- és nyugat-dunántúli késő neolitikus leletanyagokból ismert „becsehelyi” típusú szürke foltos túzkő. Ez utóbbi déli kapcsolatokra utal csakúgy, mint a boszniai vörös nyersanyag feltételezhetó szórványos elófordulása. A legtávolibb nyersanyag a C1 típusú (szlovákiai) obszidián, amiból egy darab mikropenge került elő. A felsőcsatári zöldpala jelenléte több darabbal is valószínúsíthetó. A szerszámkövek anyaga különféle szemcseméretű homokkő és kvarcit.

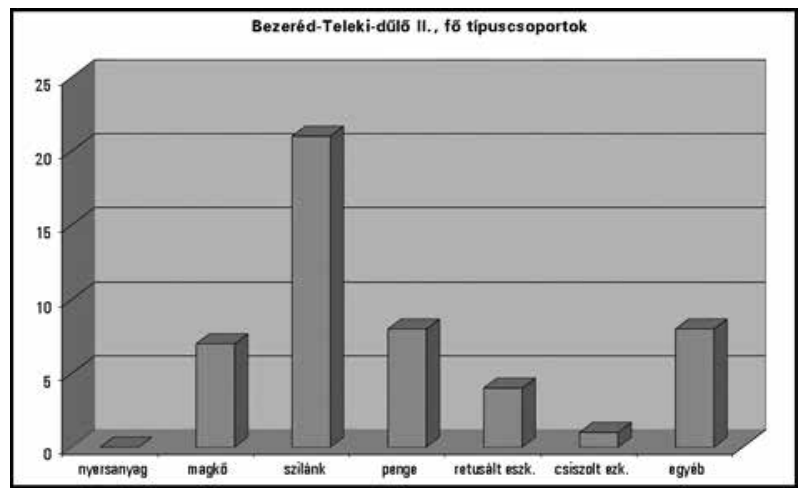

4. kép. A kőeszközleletek fó típuscsoportjai

Fig. 4. Main type groups of the stone artefacts

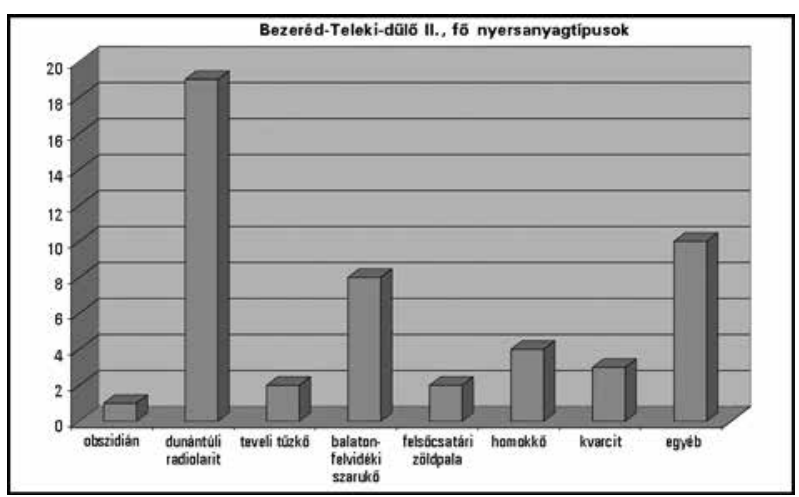

5. kép. A kőeszközleletek fő nyersanyagtípusai

Fig. 5. Main raw material type groups of the stone artefacts 


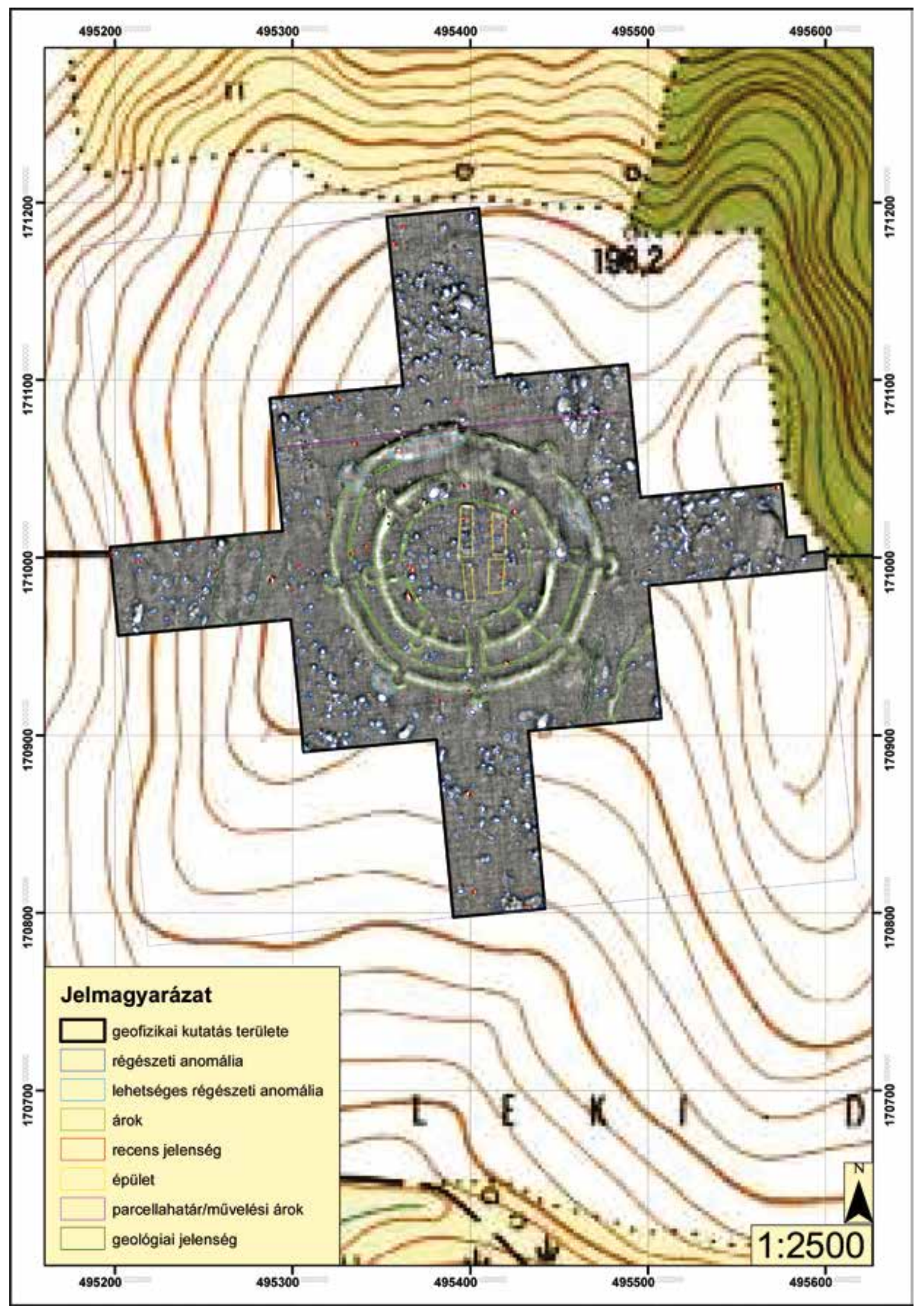

6. kép. A vertikális gradiensmérés állománya, 7 (fehér) - -7 (fekete) nT/m

Fig. 6. The result of vertical gradient measurements, 7 (white) --7 (black) nT/m 
A kőanyagot eddigi jellemzői alapján valószínúleg a késő neolitikus lengyeli kultúra, annak is inkább a korai fázisa jellegzetes anyagai közé sorolhatjuk.

A lelőhely datálása szempontjából további fogódzót nyújt a bezerédi körárokkal szerkezetük alapján párhuzamosítható, ásatással is kutatott körárkok (lásd alább) kora. Ezek közül abszolút időrendi adatok sajnos csak Szemely-Hegyes I. ${ }^{12}$ és Nagykanizsa-Palin-Anyagnyerőhely ${ }^{13}$ esetében ismertek. A Szemely-Hegyes I. külső árokcsoportjának belső árkából vett minta eredménye jól szinkronizál a nagykanizsai belső, középső és az egyik toldalékárokból származó adatokkal. A kevés rendelkezésre álló adatból messzemenő következtetések nem vonhatók le, de ez a pár eredmény azt sejteti, hogy a bejáratok előtti félköríves árkokat a körárkok létesítésének pár száz éves időszakán belül egy szúkebb időhorizontban alakították ki. ${ }^{14}$ Ezek a lengyeli kultúra klaszszikus/késői időszakára tehetók. Ez a datálás a kerámia tipokronológiai elemzéséból jelenleg levonható következtetésekkel jól, míg a kőeszközkészlet datálásával kevéssé szinkronizálható. A bezerédi körárok korának pontosabb megismerése csak ásatási eredményektől várható.

\section{A geofizikai felmérés}

\section{A módszer}

A 2014. november 5-én és november 25-én végzett felméréshez Sensys DLM típusú, Fluxgate szondákkal mérô múszert használtunk, amellyel a föld mágneses terének változásait felhasználva lehet kimutatni a felszín alatt levő természetes vagy mesterséges eredetú jelenségeket, bolygatásokat. A gradiensmérés során két egymás felett elhelyezkedő szondát használtunk egy időben. A szondák által mért térértékek különbségét alapul véve és elosztva a szondák távolságával lehet megkapni pontonként a mágneses tér vertikális gradiensének nagyságát. A földben lévő fémtárgyaknak van a legjobb mágnesezhetőségük, ezek jelentős mértékben zavarhatják a mérést. Kizárólag a mérés alapján az azonosított jel korát jellemzően nem lehet megállapítani, legfeljebb szerkezeti, formai jegyek alapján lehet egyes esetekben erre következtetni. ${ }^{15}$ A kutatási területen

12 BERTÓK-GÁTI 2011, 12.

13 TOKAI 2017, 12-13, 2-4. ábra.

14 Újabb lelőhelyek és eredmények tükrében ezek létrehozásának, használatának az idóintervalluma is tovább finomodhat.

15 A bezerédi körárok összetett alaprajza kimondottan jó lehetőségeket nyújt egy ilyen - bizonyos szerkezeti elemek morfo- egyszerre öt szondapárral végeztünk mérést, melyek egymástól 50 cm-re kerültek elhelyezésre, a mérési pontok távolsága a szelvények mentén $10 \mathrm{~cm}$ volt. Optimális esetben a mérés során a múszer hozzávetóleg 0,75-1,0 m mélységig vizsgálja át a talajt, ebből a maximális mélységből szolgáltat számunkra információkat a mérési területre jellemző talajtípus függvényében. ${ }^{16}$

A geofizikai felmérés sarokpontjait Leica VIVA GS08plus GNSS külső antennával rendelkező térinformatikai GPS-szel centiméteres vízszintes pontossággal határoztuk meg. A terepi munka során összesen 59735 m² felmérését végeztük el.

\section{A geofizikai felmérés értelmezése}

A geofizikai felmérésen sikerrel azonosítottuk a légi felvételen látható körárkot, ennek szerkezetében azonban számos új részlet jelentkezett (6. kép). Jól megfigyelhetó egy kettős körárokrendszer, melyben a belső körárok 100, míg a külső 150 méter átmérójü. Mindkét körárok esetében hozzávetőleg a négy fó és a négy mellékégtáj irányában szakadás figyelhető meg, melyek külső oldalán hat esetben egy félkörív alakú árokrészlet is azonosítható. A belső körárokhoz kívülról $(\mathrm{d}=\sim 112 \mathrm{~m})$, valamint belülról $(\mathrm{d}=\sim 70$ $\mathrm{m})$ egyaránt kapcsolódik egy-egy keskenyebb, a bejáratoknál meg-megszakadó, a belső körárokkal koncentrikus kisméretú árok, amelyeket a bejáratok két oldalán több esetben felismerhetô sugárirányú árokszakaszok kötnek össze. Méretük és jellegük alapján e keskenyebb árokszerú jelenségek paliszádfalak alapárkaiként interpretálhatók (7. kép).

A domborzati viszonyok alapján egyúttal megállapítható, hogy az említett körárkok, valamint a feltételezett paliszádfal alapárkai csak részben foglalják el a dombtetó viszonylag sík területét és a D-i oldalon már a domboldalban jelentkeznek.

A domb tetején, illetve részben annak oldalában elhelyezkedő árokrendszerek esetében felismerhetők a talajerózióból és a mezőgazdasági múvelésből eredeztethető változások is, különösen az északi és északkeleti oldalon. A fent említett hatások miatt e területrészeken csak a fó árkokra utaló elmosódott anomáliák jelentkeznek; finomabb struktúrák, mint a feltételezett paliszádfal alapárka és az árkok külső oldalán található félköríves toldalékok nem.

lógiai vizsgálatán alapuló - kronológiai elemzésre, jelen tanulmány keretei azonban ennek bemutatását nem teszik lehetővé.

16 CLARK 1986; GIBSON 1986; SCHMIDT et al. 2015, 59-67. 


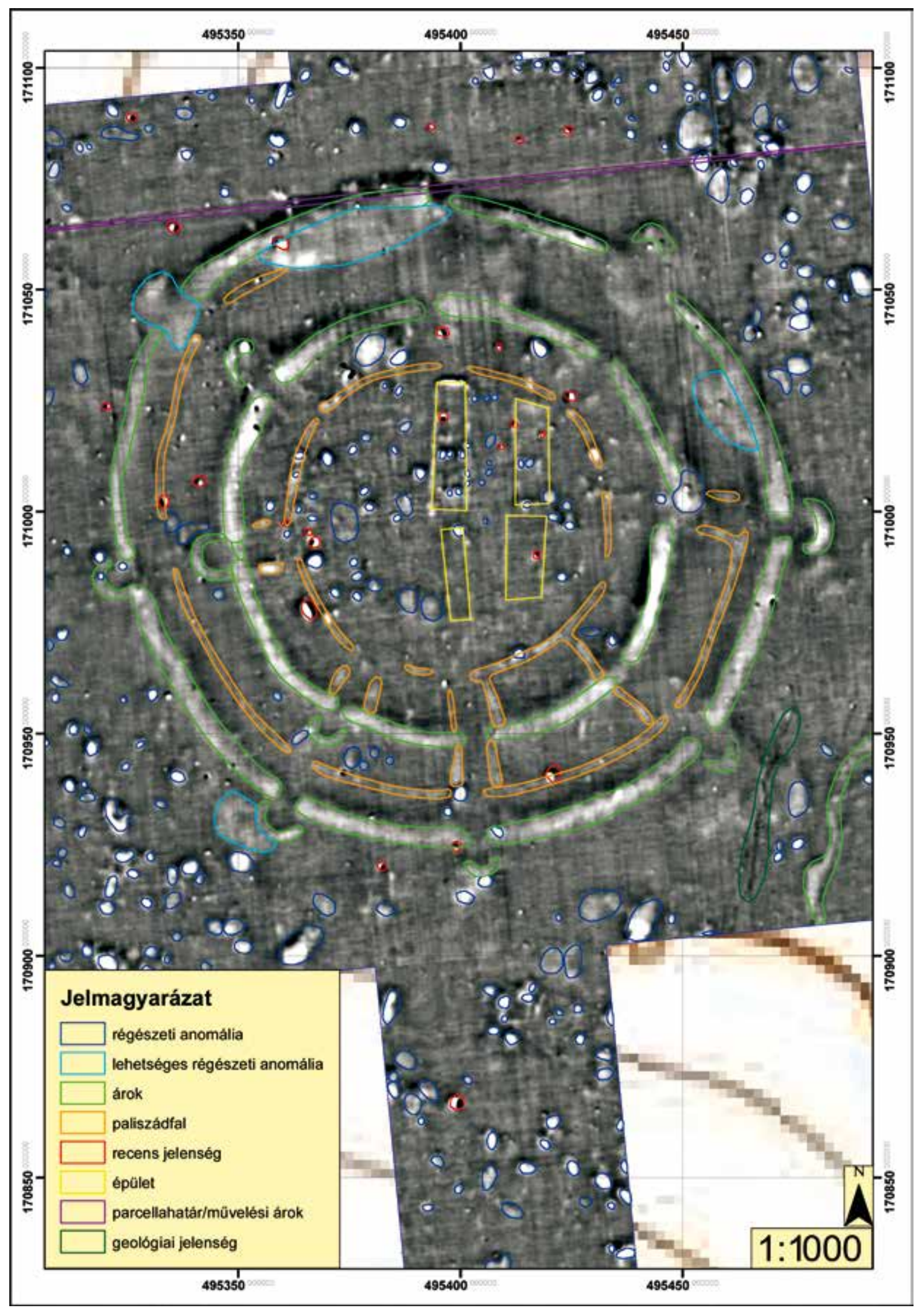

7. kép. A körárok régészetileg értelmezett alaprajza

Fig. 7. Groundplan of the archaeologically interpreted circular enclosure 
Az árkok és a paliszádfal alapárkaként interpretált jelenségek között csak igen elszórtan azonosíthatók régészeti objektumok, azonban ezek többsége az árkok és alapárkok struktúrájának része lehet - jobban kirajzolódó cölöphelyek formájában.

A belső paliszádfal által határolt, mintegy 3800-3900 $\mathrm{m}^{2}$-es területen intenzív emberi megtelepedésre utaló jelenségek ismerhetők fel. E hozzávetőleg kör alaprajzú terület K-i oldalán négy épület azonosítható, az északi két épületet a paliszádfalhoz igazíthatták. Ezen épületek hossztengelyei a mérési iránnyal párhuzamosan és a terület múvelési irányára merólegesen jelentkeztek, így a cölöplyukként interpretálható jelenségek bizonytalan jellegúek. Az épületek között, illetve azok K-i oldalán, valamint a belsó paliszádfal által határolt terület Ny-i oldalán további telepjelenségek figyelhetók meg.

A külsó körárkon kívül, annak DNy-i oldalát leszámítva egy 10-25 méter széles üres zóna figyelhető meg. A négy fóégtáj irányában végzett ráméréseken igen intenzív objektumcsoportok azonosíthatók, melyek áthúzódnak a K-i irányban lévő dombhátra, és elfoglalják a 3-10 fokos meredekségú domboldalakat is.

\section{A bezerédi körárok a lengyeli kultúrán belül}

A bezerédi körárok összetett, toldalékos árokszerkezete, illetve a belsejében észlelt épületek révén különlegesnek mondható a lengyeli kultúra körárkai közt, noha egyik szempontból sem tekinthető egyedülállónak. A külső és a belső árok átméróinek egymáshoz viszonyított 3:2 aránya alapján a bezerédi körárok a klasszikus kettős körárok formával mutat hasonlóságot, melyektől azonban a toldalékárkokkal kibővített alaprajza miatt mégis elkülönül. ${ }^{17}$

Körárkokhoz kapcsolódó toldalékárkokat eddig csak a Dél-Dunántúlról, Baranya, Somogy és Zala megyéból ismerünk, számuk összesen nyolc. ${ }^{18} \mathrm{E}$ bezerédi lelóhellyel az elterjedési határuk északabbra tolódott.

Toldalékárkos körárkok Baranya megyében Szemely, Villánykövesd és Zengővárkony határában váltak ismertté. Szemely-Hegyes I. lelőhely hármas körárokrendszerének árkain négy bejáratot alakítottak ki. A belső árkon egyszerú földhidak vannak, a középsőn az árok félkörívesen előreugrik, a külsőn többszörös, félköríves záródású, 40-45 m átmérőjú kapuszerkezet van. ${ }^{19}$

\footnotetext{
17 TRNKA 1991, 314-315.

18 P. BARNA et al. 2016, Fig. 15

19 BERTÓK-GÁTI-VAJDA 2008.
}

Szemely-Hegyes II. lelóhely legnagyobb árkának külső részéhez - és nemcsak a bejáratok elé több kisebb, félkör alakú árok csatlakozik kettes és hármas csoportokban. ${ }^{20}$ Villánykövesd-Jakabfalusi út mente lelőhelyen végzett magnetométeres felmérés alapján a külső árok bejáratai előtt de az árkoktól elkülönülve - 10 m átmérőjuu, félköríves árkok találhatók. A belső árkon kevesebb bejáratot észleltek, és félköríves árkok itt nincsenek. ${ }^{21}$ Zengővárkony-Igaz-dúlő kettős körárkán is a fó égtájak irányában nyíltak a bejáratok, közülük három ismert, a negyedik, K-i bejárata megsemmisülhetett. Itt az E-i bejárat elött van egy félköríves anomália. ${ }^{22}$

Somogy megyében két helyen, Szólád és Kaposújlak határában tártak fel hasonló jelenségeket. A Szólád-Kisaszó lelőhelyen ismertté vált körárok részletének É-i szakasza előtt került elő egy félköríves, egy periódusú árokszakasz. ${ }^{23} \mathrm{~A}$ Kaposújlak-Várdomb-dúlőben feltárt árokszakaszt a külső szélén hét, félkör alakú árok kísérte párosával. ${ }^{24}$

Zala megyéból ezt megelőzően csak Nagykanizsa-Palin-Anyagnyerőhely lelőhelyen kerültek napvilágra a bejáratok előtti félköríves árkok. A hármas árokrendszer belső árkán öt egyszerú földhíd volt, a középső árok hat bejárata közül csak háromnál, az É-i, az ÉK-i és a DNy-i bejáratok előtt bukkantunk toldalékárokra, a külső árkon pedig csak egy helyen, a K-i bejárat előtt. ${ }^{25}$

Bezeréd-Teleki-dúló II. lelőhely geofizikai felmérése alapján a külső körárkoknál talán mind a nyolc bejárat előtt - az É-i és az ÉNy-i nem egyértelmú bolygatásként értelmezhetó anomáliák miatt -, a belső körároknál pedig csak háromnál, az ÉNy-i, a Ny-i és a DNy-i előtt látszik biztosan félköríves árok (7. kép).

A körárkokhoz csatlakozó félköríves árkoknak nincs egységes elnevezése: fül, bástya, elővéd, toldalék alakban szerepel a publikációkban. ${ }^{26}$ Mindez a funkciójuk pontos meghatározásának hiányából adódik. Kaposújlak esetében felmerül a védelmi szerep, igaz itt nem is körárok, hanem egy települést kerítő, a földrajzi adottságokat figyelembe vevő íves árokrészlet került napvilágra, amely előtt hét félköríves, „bástyaszerü" árok

\footnotetext{
20 BERTÓK-GÁti 2011, 13-16, Abb. 9-11.

21 BERTÓK-GÁti 2011, 3-5, Abb. 2-3.

22 BERTÓK 2009, 132, 117-118. kép; BERTÓK-GÁTi 2011, 5-8, Abb. 4-5; BERTÓK-GÁTI 2014, 74-77.

23 OsZTÁs-MARTON-SÓFALVI 2004.

24 SOMOGYi 2004; SOMOGYI 2007.

25 TOKAI 2007; TOKAI 2008; TOKAI 2017.

26 Horváth 1998; SOMOGYI 2004; SOMOgYI 2007; TOKAI 2007; TOKAI 2008; TOKAI 2017; BERTÓK 2009; BERTÓK-GÁTI 2011; BERTÓK-GÁTI-VAJDA 2008; P. BARNA et al. 2015.
} 
volt. ${ }^{27}$ A toldalékárkok formai jegyek alapján némiképp az osztrák kutatás által felállított tipológiai rendszer 6 . bejárati típusára ${ }^{28}-$ az árok kifele, félkörívben túlnyúlik a bejárat előtt - emlékeztetnek, talán annak nagyobb méretú változataiként lehetne felfogni, azonban a magyarországi példák közepén nincs bejárat. ${ }^{29}$ Ráadásul e félköríves árkok több esetben nem is kapcsolódnak közvetlenül a körárokhoz, vagy csak az egyik oldalon van csatlakozás. A bezerédi körárok esetében a külsó árok 7. kapujánál is ezt tapasztaljuk. ${ }^{30}$ A toldalékok funkcióját tekintve a bejárat szúkítése a behaladók útjának korlátozása céljából azon félköríves ároktoldalékoknál merül fel lehetséges magyarázatként, amelyek nem zárnak teljesen vissza a fóárokhoz. A geofizikai felmérés eredményei alapján a bezerédi körárkok előtti félköríves toldalékárkok nagy részét is idesorolhatjuk. Ebből a szempontból talán kivétel a már említett 7. sz. kapu a külső körárkon, továbbá a belső körárok ugyancsak 7. sz. kapuja. Ez utóbbi, úgy túnik, mindkét végén viszszazár a fóárokhoz. Mindkét említett kapu a Ny-i fó égtáj felé nyílik.

Bezeréd esetében további kérdést vet fel a bejáratok előtti félköríves árkok és a belső körárkot a két paliszádárokkal összekötő rövid, sugárirányú, egyenes szakaszok viszonya, amit azonban csak feltárással lehetne tisztázni (utóbbiak a körárkok déli felén rajzolódnak ki jól a felmérési képen).

A körárkok belseje az ismert lelőhelyek túlnyomó többségében üres - sót egyes kutatók ${ }^{31}$ ezt a jellemzőt a körárkok egyik elengedhetetlen ismérvének tartják -, bár néhány ritka, kivételes esetben (Bučany-Kopanice, ${ }^{32}$ Bulhary-,,Gajdošova cihelna", ${ }^{3}$ Balatonmagyaród-Hídvégpuszta, $^{34}$ Villánykövesd-Jakabfalusi út mente ${ }^{35}$ ) előfordulnak épületek nyomai a belső térben. Az épületek paliszádhoz közeli, marginális elhelyezése azonban ezekben az esetekben is jelzi az építők azon szándékát, hogy minél nagyobb belső felület maradjon szabadon. Ez feltehetőleg a körárkok közösségi térként betöltött szociális szerepével állhat összefüggésben. A bezerédi körárok belsejében kimutatható épületek száma - nagy

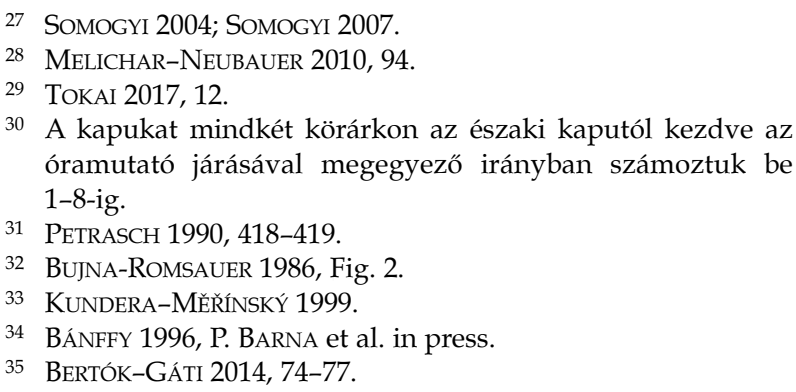

valószínúséggel négy - meghalad minden eddig ismert példát, mivel azonban az épületek egymáshoz, illetve a körárok aktív használati idejéhez viszonyított időrendi helyzetéről nem rendelkezünk konkrét adatokkal, ebből a tényből további következtetéseket nem vonhatunk le. A két északi épület alaprajzi igazodása a belső körárok vonalához elvileg felveti az épületek és a belső körárok egyidejúségének lehetőségét. PolgárCsőszhalom többszörös, lengyeli típusú körárokkal kerített tell településén a paliszádárkok és a házhelyek elrendezése, egymáshoz való térbeli viszonya hasonló, mint a bezerédi esetben. ${ }^{36}$ Ezzel szemben a korai lengyeli kultúrára datált klasszikus alaprajzú bučanyi körárok, valamint a belsejében álló, a lengyeli kultúra fiatalabb (II.) fázisára jellemző megaron típusú épület esete ${ }^{37}$ arra figyelmeztet, hogy ez az összetett kérdés pusztán a geofizikai felmérés alapján nem válaszolható meg.

Mint már esett szó róla, a bezerédi körárok közvetlen közelében több, szintén lengyeli datálású lelőhely is található (2. kép). Egyelőre arra nézve nem rendelkezünk adatokkal, hogy ezek közül melyek lehetnek egykorúak a körárok használati idejével. E lelóhelyek földrajzi közelségét tekintve felvetődik a kérdés, hogy valóban több különböző lelóhelyról van-e szó, melyek közt a körárkos lelóhely központi elhelyezkedésû, vagy egyetlenegy nagy lelőhelykomplexumként értelmezhetók-e a településtörténeti adatok. E kérdés eldöntéséhez szintén további kutatásokra lenne szükség.

\section{A körárok tájolása, elhelyezkedése a tájban}

A magnetométeres felméréssel a körárok teljes alaprajzát sikerült felfedni. Nagy valószínúséggel 8 szimmetrikusan elhelyezett kapu szakítja meg a két, szinte szabályos kör alakú árok folytonosságát. A bezerédi kettős körárokrendszer alaprajza feltúnően szimmetrikus. A két árok alaprajza szinte tökéletes kör, és bár a központ helyét az alaprajzon nem találjuk meg, s feltehetően nem is jelölték, mégis a két kör majdnem koncentrikus (a külső körárok központja kissé délebbre, kb. 3-5 m-re van a belső körárokénál). Ez azt jelenti, hogy vagy nagyjából „közös” központ körül rajzolták meg az árkokat, vagy ha nem, akkor rendkívül gondosan mérték ki a külső körárkot a belsőhöz képest (a két körvonal között mindenütt kb. $22 \mathrm{~m}$ a távolság).

36 RACZKY-SEBŐK 2014.

37 Bujna-Romsauer 1986; PAŽinová 2007, 299-302; PAŽInOvá 2011, 129. 
A tájolás szempontjából a kapuk által meghatározott irányokat két csoportba oszthatjuk. Az 1., 3., 5. és 7. kapuk a fó világtájak közelében vannak. A 8. képen jól látható, hogy a D-i, Ny-i és az É-i kapupárokat összekötő tengelyek merőlegesek egymásra. Eltérés csak a 3. sz. (keleti) kapuknál látható. Ott a belső kapu rajta van a tengelyen, viszont a külső kapu eltér attól, kb. 10 fokkal.

A 2., 4., 6. és 8. kapu a mellékvilágtájak zónájába esik. Rájuk is igaz az állítás, hogy az összekötő tengelyek merólegesek egymásra.

Mindez megerósíti a korábbi állításunkat, miszerint az alapítási rítus által rögzített (keleti) kapu kivételével a többi kaput szerkesztéssel jelölték $\mathrm{ki}^{38}$ hiszen nehéz lenne olyan négy-négy tájolási célpontot találni, amelyekhez a tájolás egymásra derékszögú irányokat eredményezne. Olyan szerkesztési elvet alkalmaztak, amelyben a szimmetriára való törekvés volt a meghatározó.

A Bezeréd-Teleki-dúlő II. lelőhelyen felfedezett kettős körárokrendszer tájolási sajátosságai ismételten megerősítik azt az állításunkat is, miszerint a lengyeli kultúra körárkainak alapítási rítusában a felkelő nap döntő szerepet játszott. ${ }^{39}$ Elméletünket 2008-ban több mint 50, késő neolit körárokrendszer adataira támaszkodva dolgoztuk ki. A vizsgálatba bevont körárokrendszerek több mint 90\%-ának keleti oldalán található volt egy kapu, amely a nappályára, tehát az év két napján a felkelő nap irányába nézett. Ezeknek a kapuknak a tájolási értéke így a téli és nyári napforduló napkeltéi által bezárt tartományba esett. 2008 óta sem vált ismertté egyetlen olyan újonnan felfedezett körárokrendszer, amely ellentmondana elméletünknek.

A bezerédi kettős körárok esetében a keleti oldalon lévő kapukból a 3. kapuk iránya mutat a nappályára. A belső körárok 3 . kapuja rajta van a szimmetriatengelyen (8. kép), így feltehetően annak kitúzése történhetett meg az alapítási rítus keretében; a külső 3. kaput azonban már minden bizonnyal nem az alapító rítus keretében jelölték ki.

A belső 3. kapu tájolási értéke alapján a kitúzés (alapítás) ideje március/szeptember vége lehetett. A teljes körárokrendszer kiépítésének időtartama - klimatikus okokból - feltételezhetóen egy évszakra korlátozódott. ${ }^{40}$ Elfogadhatónak tartjuk azt a véleményt, hogy a körárkokat egyetlen,

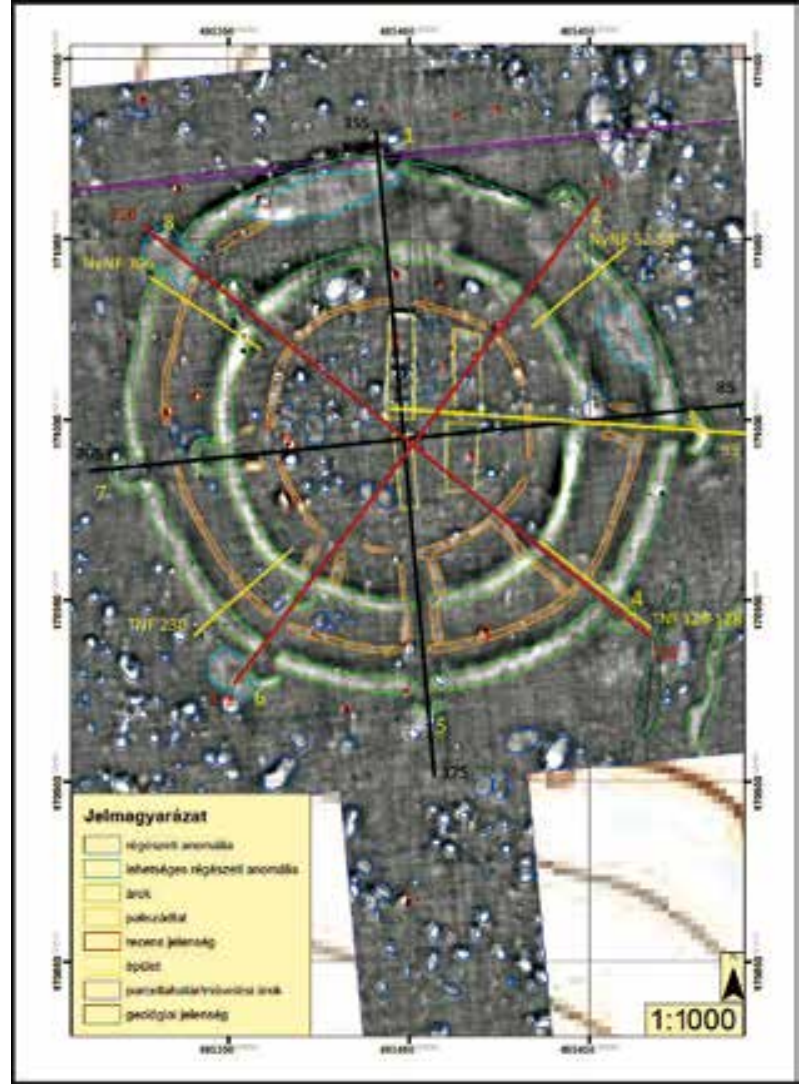

8. kép. A körárok tájolási jellemzői. NYNF = nyári napforduló, $\mathrm{TNF}=$ téli napforduló

Fig. 8. Orientation characteristics of the circular enclosure. $\mathrm{NYNF}=$ summer solstice, $\mathrm{TNF}=$ winter solstice

előre meghatározott terv szerint építették, ${ }^{41}$ ugyanakkor figyelembe véve a korabeli technikai feltételeket, ${ }^{42}$ számolnunk kell kisebb-nagyobb alaprajzi torzulásokkal, pontatlanságokkal is.

A mellékvilágtájak zónájában elhelyezett kapuk közül a DK-i kapu a téli napforduló napkeltéjének irányába néz. Ez felveti a kérdést, hogy vajon szándékosan tájolták-e ezt a kaput a napmozgás évi pályájának szélső pontja felé, ahol az égitest kb. 2 héten át tartózkodik, vagy csak a szimmetriára törekvő szerkesztés okozta véletlen egybeesésnek köszönhető ez az érték?

A körárokrendszer topográfiai elhelyezése is beleillik a Nap fontosságát hangsúlyozó elméletünkbe. ${ }^{43} \mathrm{~A}$ domborzati modell tanúsága szerint a körárokrendszer egy kúp alakú, a környezetéból jelentősen kiemelkedő domb tetején, annak is kissé a déli lejtője felé elcsúszva helyezkedik

\footnotetext{
38 PÁszTor et al. 2014.

39 PÁszTor et al. 2008.

40 KAŽDOVÁ-Weber 1990, 165.
}

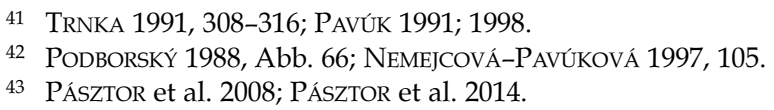




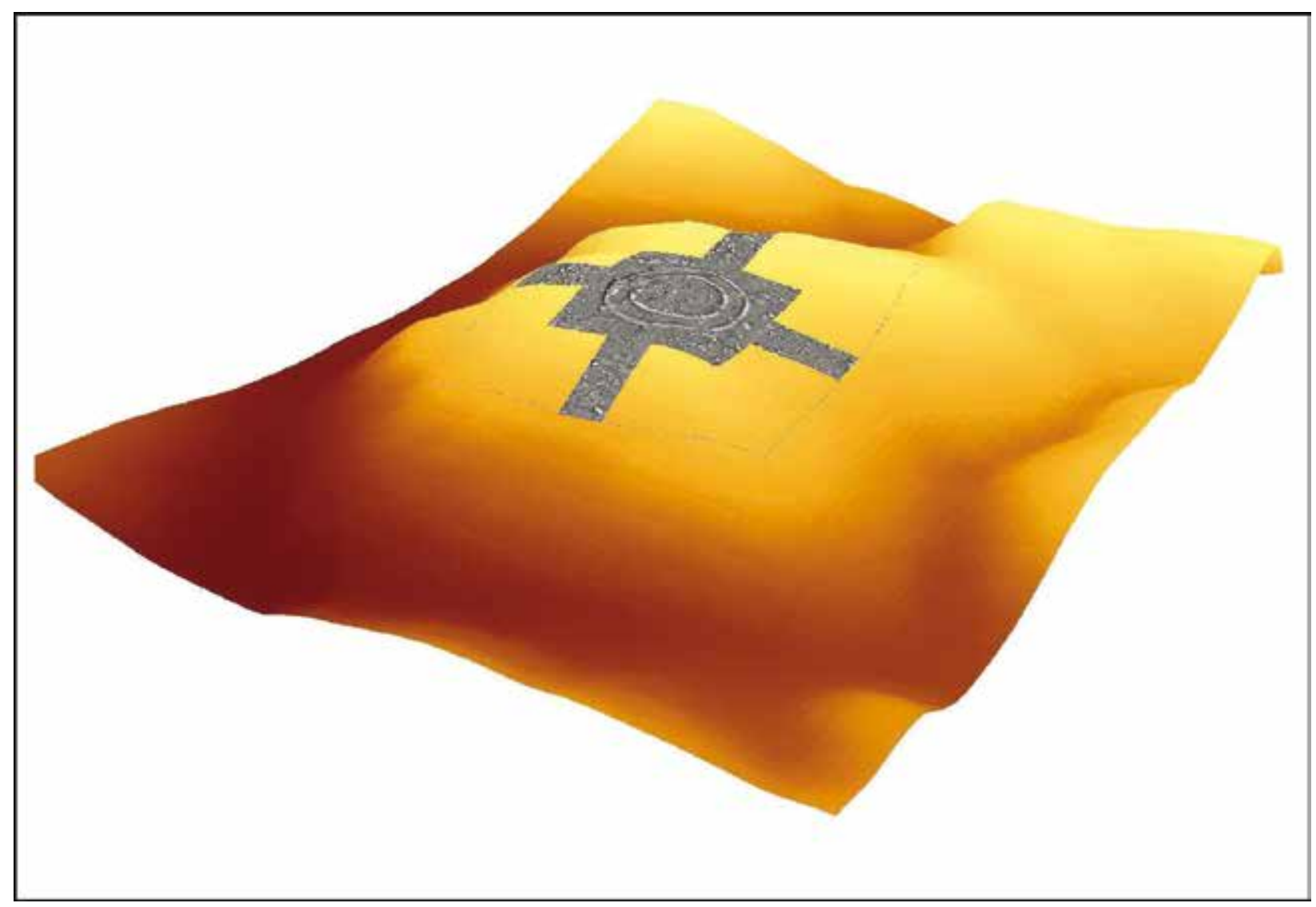

9. kép. A körárok domborzati modellen megjelenítve

Fig. 9. The circular enclosure system represented on a digital elevation model

el, ahonnan kiváló „kilátás” nyílik a nappályára (9. kép).

Bár a kapuk körül látható toldalékok a körárokrendszer korát a késői időszakra datálják, az alaprajz feltúnően szimmetrikus és szabályos kör alakja azt sugallja, hogy az építők még mindig ismerték és tiszteletben tartották a körárkok építésének szabályait. Bezeréd a Nyugat-Dunántúlon belül azon a területen található, ahol a körárkok építésének kanonizált, szakrális szabályai megszülettek..$^{44}$ A távolabbi területeken található (toldalékos) körárkok már nem ilyen szabályosak. A körárkok - mint szakrális területek - építését rituálisan kötött elvek szabályozhatták, és ezek az elvek az eredet helyén maradtak fenn a legtovább változatlan vagy alig módosult formában.

\section{Összefoglalás}

A Bezeréd-Teleki-dúlő II. lelőhelyen geofizikai felméréssel vizsgált kettős körárokrendszer kiemelkedik az eddig feltérképezett Zala megyei körárkok sorából: rendkívül szabályos és összetett alaprajza, valamint a belsejében felmért épületek minden jelenleg ismertnél nagyobb száma további figyelmet érdemel. Célunk a lelőhely kutatásának folytatása: szisztematikus terepbejárást követően ásatással is tervezzük kutatni a lelőhelyet, elsősorban stratigráfiai és abszolút kronológiai adatok gyújtése céljából. Szintén terveink közt szerepel a környező, hasonló korú lelőhelyekkel való összefüggések tisztázása nagy felületú geofizikai felmérés segítségével. 


\section{IRODALOM}

BÁNFFY ESZTER

1996 Kora rézkori körárok Balatonmagyaród-Hídvégpusztáról. In: Vándor L.-Költő L. (szerk.): Évezredek üzenete a láp világából (Régészeti kutatások a Kis-Balaton területén 1979-1992). Zalaegerszeg, 21-22.

P. BARNA, JUdiT -PÁSZTOR, EMÍLIA

2011 Different Ways of Using Space. Traces of Domestic and Ritual Activities at a Late Neolithic Settlement at Sormás-Török-földek. Documenta Praehistorica (Ljubljana) 38, 185-206.

P. BARNA JUdit-TOKAi Zita MÁria-Eke IstVÁn-PÁsztor EMília

2015 A késő neolitikus körárkok kutatásának helyzete Zala megyében (Current research on Late Neolithic rondels in Zala County). Archeometriai Múhely (Budapest) 12:2, 75-88.

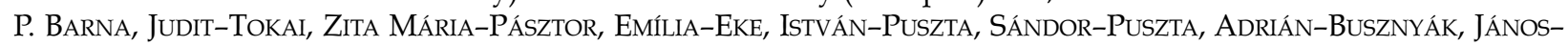
T. Bíró, KATALIN-SZÁRAZ, CSILla

2016 Late Neolithic Circular Ditch Systems in Western-Hungary. Overview on the present stage of research in Zala County, Hungary. In: Kovárník, J. (ed.): Centenary of Jaroslav Palliardi's Neolithic and Aeneolithic Relative Chronology. Hradec Králové 2016. Hradec Kralové. 309-336.

P. BARNA, JUDIT-BÁNFFY, ESZTER-SERLEGI, GÁBOR-FulLÁR, ZOLTÁN

In press Circular Enclosure and Settlement from the mid-5th Millennium BC at Balatonmagyaród-Hídvégpuszta. In: Bánffy, E.-P. Barna, J. (eds) „Trans Lacum Pelsonem.” Prähistorische Forschungen in Südwestungarn (5000-500 V.U.Z.) Prehistoric Research in South-Western Hungary (5000-500 BCE), CPP 7, Frankfurt am Main-Keszthely-Leipzig-Rahden/Westf.

BERTÓK, GÁBOR

2009 Lelőhelyfelderítés és interpretáció légi régészeti, fotogrammetriai, geofizikai és térinformatikai módszerek alkalmazásával. Baranya megye légi régészeti topográfiája. Doktori disszertáció. Budapest.

BERTÓK, GÁBOR-GÁTI, CSILLA

2011 Neue Angaben zur spätneolithischen Siedlungsstruktur in Südosttransdanubien. Acta Archaeologica Academiae Scientiarum Hungaricae (Budapest) 62, 3-8, Abb. 2-5.

2014 Régi idők - új módszerek. Roncsolásmentes régészet Baranyában 2005-2013. Archaeolingua, BudapestPécs, 2014.

BERTÓK GÁbOR-GÁti Csilla-VAJdA Olga

2008 Előzetes jelentés a Szemely-Hegyes lelőhelyen (Baranya megye) található neolitikus körárok-rendszer kutatásáról (Preliminary report on the research at the neolithic Kreisgrabenanlage at Szemely-Hegyes, Baranya County, Hungary). Archaeologiai Értesítő (Budapest) 133, 85-106.

T. BIRÓ, KATALIN

1998 Lithic Implements and the Circulation of Raw Materials in the Great Hungarian Plain during the Late Neolithic Period. Magyar Nemzeti Múzeum, Budapest.

Bujna, JOZEF-ROMSAUER, PeTER

1986 Siedlung und Kreisanlage der Lengyel-Kultur in Bučany. In: Chropovsky, B.-Friesinger, H. (eds): Internationales Symposium über die Lengyel-Kultur. Nitra-Wien, 27-35.

CLARK, ANTHONY J.

1986 Archeological Geophysics in Britain. Geophysics (Tulsa, Oklahoma [USA]) 51, 1404-1413.

GiBSON, TERRANCE H.

1986 Magnetic Prospection on Prehistoric Sites in Western Canada. Geophysics (Tulsa, Oklahoma [USA]) 51, 553-560.

HOLUB JóZSEF

1933 Zala megye története a középkorban, III. kötet, A községek története - Kézirat.

HORVÁth LÁSZLÓ

1998 Nagykanizsa és környékének fontosabb őskori és római kori régészeti lelőhelyei. Nagykanizsai Honismereti Füzetek (Nagykanizsa) 20, 12-13.

Horváth, LÁsZló ANDRÁs-H. SimON, KATALIN

2003 Das Neolithikum und die Kupferzeit in Südwesttransdanubien: Siedlungsgeschichte und Forschungsstand. Inventaria Praehistorica Hungariae 8. Budapest, 54-55.

KAŽDOVÁ, ELIŠKA-WEBER, ZDENĚK

1990 Architektur der Lengyel-Rondelle im mittleren Donauraum. Jahresschrift für Mitteldeutsche Vorgeschichte 73. Berlin, 159-169.

KUNDERA, LUBOMÍR-MĚǨíNSKÝ, ZDENĚK

1999 Bulhary, okr. Břeclav. In: Podborský, V. et al.: Pravěká sociokultovní architektura na Moravě. Brno, 41-55.

Melichar, Peter-Neubauer, WolfGang (HrsG.)

2010 Mittelneolitische Kresigrabenanlagen in Niederösterreich. Mitteilungen der Prähistorischen Kommission, 71 , Wien. 
NĚMEJCOVÁ-PAVÚKOVÁ, VIERA

1997 Kreisgrabenanlagen der Lengyel-Kultur in Ružindol-Borová. Studia Archaeologica et Mediaevalia, Tomus III. Univerzita Komenského. Bratislava.

OszTÁs ANETT-MARTON TibOR-SÓFALVI ANDRÁS

2004 Szólád-Kisaszó. In: Honti et al. (szerk.): A tervezett M7-es autópálya Somogy megyei szakaszának megelőző régészeti feltárása III. (2002-2003). Somogyi Múzeumok Közleményei (Kaposvár) 16, 61-62.

PÁSzTOR, EMília-P. BARNA, JUdiT-ZotTI, GEORG

2014 Neolithic Circular Ditch Systems ("Rondels”) in Central Europe. In: Clive L. N. Ruggles (ed.) Handbook of Archaeoastronomy and Ethnoastronomy. Heidelberg, 1317-1326.

PÁszTor, EMília-P. BARNA, JudiT-ROSLUnd, CuRT

2008 The Orientation of Rondels of the Neolithic Lengyel Culture in Central Europe. Antiquity (Durham) 82, 910-924.

PAVÚK, JURAJ

1991 Lengyel Culture Fortified Settlements in Slovakia. Antiquity (Durham) 65, 348-357.

1998 Hlavnévýsledky výskumu sídliska lengyelskej kultúry v Žlkovciach (Substantial research results of the

PAŽINOVÁ, NOEMI Lengyel Culture site in Žlkovce). Slovenská archeológia (Nitra) 46:2, 169-186.

2007 The Lengyel Culture Settlement in Bučany (Preliminary report on pottery processing). Documenta Praehistorica (Ljubljana) 34, 299-310.

PETRASCH, JÖRG

1990 Mittelneolithische Kreisgrabenanlagen in Mitteleuropa. Bericht der Römisch-Germanischen Kommission (Frankfurt a. M.) 71, 407-564.

PODBORSKÝ, VLADIMÍR

1988 Těšetice-Kyjovice IV. Rondel osady lidu s moravskou malovanou keramikou, Brno.

RACZKY, PÁL-SEBöK, KATALiN

2014 The Outset of Polgár-Csőszhalom Tell and the Archaeological Context of a Special Central Building. ARCHAEOVEST (Timişoara) II, 51-100.

Schmidt, Armin-Linford, PAul-Linford, Neil-David, Andrew-GaffneY, Chris-Sarris, Apostolos-Fassbinder, JörG 2015 EAC Guidelines for the Use of Geophysics in Archaeology. http://old.european-archaeological-council. org/files/eac_guidelines_2_final.pdf (elérés: 2018. 04.03).

SOMOGYI, KRISZTINA

2004 Előzetes jelentés a Kaposvár 61-es elkerülő út 29. számú lelőhelyén, Kaposújlak-Várdomb-dúlőben 2002-ben végzett megelőző feltárásról (Preliminary report on the preceding excavation of site number 27. of the Route 61 encircling Kaposvár). Somogyi Múzeumok Közleményei (Kaposvár) 16, 165-178.

2007 Die besonderen Grabenanlage der Lengyel-Kultur in Kaposújlak-Várdomb-dúló im Komitat Somogy (SW-Ungarn). In: Kozłowski, J. K.-Raczky, P. (eds): The Lengyel, Polgár and Related Cultures in the Middle/Late Neolithic in Central Europe. Kraków, 329-344.

TOKAI ZITA MÁRIA

2007 Nagykanizsa-Palin, Anyagnyerőhely. In: Kisfaludi J. (szerk): Régészeti Kutatások Magyarországon, 2006 (Archaeological excavations in Hungary, 2006). Budapest, 236-237.

20080711 Nagykanizsa-Palin - Anyagnyerőhely. In: Horváth L.-Frankovics T. (szerk.): Régészeti feltárások az M7-M70 autópálya Zala megyei nyomvonalán. Összefoglaló jelentés az 1999-2008 között végzett feltárásokról. Zalaegerszeg, 56-58.

2017 Nagykanizsa-Palin-Anyagnyeróhely - egy központ a lengyeli kultúra idejéből. Zalai Múzeum (Zalaegerszeg) 23, 7-30.

TRNKA, GERHARD

1991 Studien zu mittelneolithischen Kreisgrabenanlagen. Mitteilungen der Prähistorischen Kommission der Österreichischen Akademie der Wissenschaften 26. Österreichische Akademie der Wissenschaften. Wien. 


\title{
BEZERÉD-TELEKI-DÜLŐ II. - A LATE NEOLITHIC CIRCULAR ENCLOSURE FROM THE 5TH MILLENNIUM BC
}

\author{
Judit P. Barna-Zita Mária ToKai-IstvÁn Eke-Emília PÁsZtor-Katalin T. BirÓ-GÁbor MesterháZy-MihÁly Pethe
}

This is a preliminary report of a Late Neolithic circular enclosure (Fig. 1.7) at a site at Bezeréd-Teleki-dúlő II discovered in a satellite photograph ${ }^{1}$ in 2014 . The patch of the documented feature is visualised with sharp outlines so clearly that - as we realised later based on the geophysical measurement - even several structural elements can be identified in the satellite photograph. ${ }^{2}$ Bezeréd village is situated in Zala County (Western Hungary) on the northern part of the Zalaapáti ridge micro region. The Zalaapáti ridge - a hill running long in north-south direction - lies between the Zala River and the Principális canal.

There are several sites dated to the Lengyel culture at the borders of Bezeréd (Fig. 2). The site Bezeréd-Telekidúló $\mathrm{II}^{3}$ can be found on the upper part of a hill emerging more than 35 metres out of its surroundings. The top of the hill is a flat, extended plateau. In the aerial photos ${ }^{4}$ and satellite photos taken of the site, a large, approximately round anomaly can be seen.

In spite of the fact that we have not completed any systematic field walking at the site, we collected a few, but characteristic ceramic and lithic finds from the surface in a then newly-ploughed land strip. There are only very few pieces of information about the find assemblage at our disposal, therefore we can provide merely a rough picture of it (Fig. 3.1-17). Based on this, the finds can be dated to the classical or younger classical phase of the culture.

During the field walking, 49 lithic finds came to light in total. The type/raw material matrix of the collected lithic finds is shown in Table 1. The main type groups can be seen in Fig. 4, and the main groups of raw materials are shown in Fig. 5. The lithic assemblage, based on its characteristics, can be dated to the Late Neolithic Lengyel culture, indeed, to the earlier phase of it.

For the dating of the site, a further point of reference can be the dating of circular enclosures with structures similar to the Bezeréd circular enclosure, and which were also excavated. From among these, absolute chronological data are known only from the sites at Szemely-Hegyes $\mathrm{I}^{5}$ and Nagykanizsa-Palin, Anyagnyeróhely. ${ }^{6}$ These few data suggest that the semicircular affixes were built during a shorter period of the era of the circular enclosures.?

For the measurement we used a Sensys DLM 5-channel magnetometer with Fluxgate probes. The layout of the geophysical survey was aligned by using a Leica

1 Google Earth, 14.04.2014.

P. BARNA et al. 2016, Fig. 14

Identification number of the site: 20307.

www.fentrol.hu (1985, 132_6938).

BERTÓK-GÁTI 2011, 12.

TOKAI 2017, 12-13, Figs. 2-4.

In the light of further new sites and results, the date of the establishment of structures with semicircular affixes might be specified more accurately.
VIVA GS08plus GNSS Receiver. During the field work, we measured a 59,735 $\mathrm{m}^{2}$ large area altogether. In general, based on the measurement, the age of the identified sign cannot be determined. At most, it can be deducted from structural, formal features in some cases. ${ }^{8}$

As a result of the geophysical survey, a dual circular enclosure is clearly visible (Fig. 6), of which the inner enclosure is $100 \mathrm{~m}$ in diameter, and the outer one is $150 \mathrm{~m}$. In both cases, openings towards approximately the four Cardinal directions and the four Primary Intercardinal directions can be detected. Two narrow ditches are connected to the inner enclosure both on its outer $(d=\sim 112$ $\mathrm{m})$ and inner sides $(\mathrm{d}=\sim 70 \mathrm{~m})$. These narrow ditches are concentric to the inner enclosure and there are openings on them matching with openings of the two enclosures. In some cases, there are straight ditch sections on both sides of the openings of the narrow ditches connecting the larger and the smaller narrow circular ditches. Based on their size and character, these narrow ditch-like features can be interpreted as foundation ditches of palisades. On the inner, approximately 3,800-3,900 $\mathrm{m}^{2}$ large space encircled by the inner enclosure, features referring to intense human inhabitation can be recognized. Four buildings were identified in the eastern part of this approximately round territory, the two northern buildings might have been set to the palisade. A $10-25 \mathrm{~m}$ wide zone free from archaeological anomalies can be detected around the circular enclosure except for its southwestern section. Fairly intense groups of features are visible in the longish strips measured towards the cardinal points, a part of which extend on the hill east of the site.

The Bezeréd circular enclosure can be regarded as a special example among the circular enclosures of the Lengyel culture, albeit it cannot be taken as a unique circular enclosure. According to the 3:2 ratio of the diameters of the outer and inner ditches, it has similarities with the classical double circular enclosure form ${ }^{9}$ from which it still differs due to its affixes. To date, circular enclosures with affixes are known only from the SouthernTransdanubian area, from Baranya, Somogy and Zala Counties. There are eight of these. ${ }^{10}$ The northern border of their spread extended towards the north with the discovery Bezeréd site.

Semicircular affixes can be seen in front of all the eight gates of the outer enclosure, and in front of only three gates of the inner enclosure based on the geophysical sur-

8 The multiple layout of the Bezeréd circular enclosure offers a pronouncedly good opportunity for such a chronological examination based on a morphological evaluation of several structural elements. Within the framework of this paper, we cannot present this.

9 TRNKA 1991, 314-315.

10 P. BARNA et al. 2016, Fig. 15. 
vey (Fig. 7). The relation among the semicircular affixes in front of the gates and the straight ditches connecting the inner circular enclosure with the two palisades is considerably notable. The research has not been able to identify the function of the semicircular affixes. A part of these do not join immediately to the circular enclosure or there is connection only on one side (e.g. in case of gate No. 7 on the outer ditch of the Bezeréd circular enclosure ${ }^{11}$ ). Narrowing the openings, limiting the pass into the inner space of the enclosure can be taken into consideration as possible function of the affixes in those cases where they do not join to the main ditch. Most of the cases of the Bezeréd affixes can be classified in this group. The outer and inner gates of No. 7 may be exceptions to that rule.

Archaeological features cannot be detected in most cases in the inner spaces of circular enclosure, nonetheless traces of buildings appear in some rare, exceptional cases (Bučany-Kopanice, ${ }^{12}$ Bulhary, ${ }_{1}^{13}$ BalatonmagyaródHídvégpuszta, ${ }^{14}$ Villánykövesd-Jakabfalusi út mente ${ }^{15}$ ). The intention of the builders to avoid as large space free as possible is shown by the fact that the buildings were built marginally, close to the palisade. The number of the buildings (4) inside the Bezeréd enclosure exceeds all the examples known to date. We do not have data considering the chronological relationship among the buildings on one hand and among the buildings and the time of the active use of the circular enclosure on the other hand.

We do not know that of the Lengyel sites lying in straight vicinity of the Bezeréd circular enclosure how many can be contemporary with the active use of the enclosure. Taking into consideration their geographical vicinity, a question is raised: are these locations genuine independent sites amidst which the site with the circular enclosure has a central position, or these settlement historical data can be interpreted as a single, huge site complex?

The layout of the double circular enclosure at Bezeréd is remarkably symmetrical. The two ditches are almost perfect circles and the two circles are almost concentric.

The directions defined by the gates can be divided into two orientation groups. Gates No. 1, 3, 5 and 7 face towards the Cardinal directions and their range. Fig. 8 shows clearly that the axes of the inner and outer gates at the southern-northern openings are the same while the axe of the western gate pair ${ }^{16}$ is perpendicular to the north-south one.
Difference can be seen only at the eastern outer gate. There the inner gate is on the axis, but the outer gate diverges approximately 10 degrees. The directions of gates No. 2, 4, 6 and 8 fall into the area of Primary Intercardinal directions. It is also true that their connecting axes are perpendicular to each other.

This confirms our earlier statement that apart from the (eastern) gate fixed by the foundation ritual, they carefully marked the place with geometric editing for the other gates. ${ }^{17}$ Aspiration for symmetry was the chief principle.

Our theory - that the rising sun played a significant role in the design of Late Neolithic circular enclosures ${ }^{18}$ - was based on the data of over 50 circular enclosures (rondels) collected in 2008.

More than $90 \%$ of the investigated circular enclosures had a gate on the eastern side which was aligned to the trajectory of the rising sun, therefore their orientation falls between the range closed by the midwinter and midsummer sunrise.

Since 2008, none of the newly discovered ditch systems have contradicted our theory.

In case of the double ditch enclosure of Bezeréd, gate No. 3 among the eastern gates faces the sun path. As the inner circle's third gate is sitting on the symmetrical axis (Fig. 8), probably it was ritually founded by the first beams of the rising sun. The third outer gate, however, was certainly not designated under the foundation ritual.

The south-eastern gate of the intercardinal zone faces the midwinter sunrise. However, it is not clear here, whether the gate was truly oriented to this astronomical event or only the pursuit to symmetry resulted in this orientation.

The topographical location of the enclosure - close to the top of a hill, on the southern slope - also verifies our theory on the importance of the sun. ${ }^{19}$

Bezeréd site is situated in Western Transdanubia, in the area where the canonized, sacred rules of the construction of circular enclosures (rondels) were born.

The circular enclosures (with additional semicircular ditches) in areas further away are no longer as regular as this. Construction of the sacred circular earthworks could have been governed by ritualized principles which survived without any or hardly any alteration the longest at their place of origin.

We plan a large-scale geophysical survey and an excavation at the site in the future.

\footnotetext{
11 We counted clockwise the gates starting from the northern gate in the cases of both ditches.

12 Bujna-Romsauer 1986. Fig. 2.

13 KUNDERA-MĚŘínSKÝ 1999

14 BÁNFFY 1996; P. BARNA et al. in press.

15 BERTÓK-GÁTI 2014

16 Except the outer gate No. 3 (in details see below).
}

17 PÁszTOR et al. 2014.

18 PÁszTOr et al. 2008.

19 PÁszTor et al. 2014; PÁszTOr et al. 2008. 